\title{
Rediscovery and lectotypification of Ophiorrhiza brunonis var. johnsonii (Rubiaceae) - an endemic variety of the southern Western Ghats, India
}

\author{
Akhilesh S.V.N. ${ }^{1}$, Gangaprasad A. ${ }^{1 *}$ \& K.B. Rameshkumar ${ }^{2}$ \\ ${ }^{1}$ Centre for Biodiversity Conservation, Department of Botany, University of Kerala, Kariavattom, \\ Thiruvananthapuram, Kerala - 695 581, India \\ ${ }^{2}$ KSCSTE-Jawaharlal Nehru Tropical Botanic Garden and Research Institute, Palode, Thiruvananthapuram, Kerala - 695562 , India \\ *E-mail: agangaprasad@yahoo.com
}

\begin{abstract}
Ophiorrhiza brunonis var. johnsonii Hook.f. is rediscovered after a gap of 140 years of its first collection, from Chemunji hills of Agasthyamala Biosphere Reserve of southern Western Ghats of India. It is reported here with a detailed taxonomic description, stereo microscope images and SEM images of pollen.
\end{abstract}

Keywords: Chemunji hills, Nomenclature, Pollen, Taxonomy, Typification.

\section{Introduction}

The genus Ophiorrhiza L. comes under tribe Ophiorrhizeae, subfamily Rubioideae of the family Rubiaceae (Bremer \& Eriksson, 2009), comprises 382 species distributed mainly in the wet tropical and subtropical forests of Southeast Asia, ranging to Australia, New Guinea and the Pacific Islands (Deb \& Mondal, 1997; POWO, 2021). It is represented by 52 species in India, distributed mainly in the Western Ghats and northeastern states of India (Hareesh \& Sabu, 2018). Of these, 27 taxa are distributed in the Western Ghats, and of those, 16 are endemic to the Western Ghats (Nayar et al., 2014).

During one plant exploration field trip, the authors collected specimens of Ophiorrhiza from Chemunji hills in Agasthyamala Biosphere Reserve in Kerala. On critical comparative study with the relevant

Received: 10.05.2021; Revised \& Accepted: 11.07.2021

Published Online: 31.12.2021 literature (Hooker, 1880; Gamble, 1921; Deb \& Mondal, 1997), it was identified as O. brunonis var. johnsonii Hook.f., and confirmed the identity by comparison with the type specimen images at Kew Herbarium (K000031150, K000031151, digital images!).

Hooker (1880) described Ophiorrhiza brunonis var. johnsonii based on Rev. E. Johnson's collection from the erstwhile princely state of Cochin. It is assumed that Rev. Johnson's has collected the variety between 1860 and 1865, but the exact date of collection and precise locality is unknown even today. Gamble (1921) and Deb and Mondal (1997) included this variety based on original collections by Rev. Johnson. Hence the present collection represents a rediscovery of this variety after a gap of more than 140 years.

\section{Taxonomic Treatment}

Ophiorrhiza brunonis var. johnsonii Hook.f., Fl. Brit. Ind. 3:80. 1880; Deb \& Mondal, Bull. Bot. Surv. India 39 (1-4): 34. 1997.

Lectotype (first-step designated by Deb \& Mondal, 1997; second step designated here): INDIA, Kerala, Cochin, s.d. Johnson s.n. (K [K000031150 digital image!]); isolecto (K [K000031151 digital image!]).

Figs. $1 \& 2$

Herbs, 10-25 cm tall; stems erect, puberulous. Leaves $7-12 \times 2.5-4 \mathrm{~cm}$, ovate-lanceolate, acuminate at apex, cuneate at base, thin, membranous, glabrous 

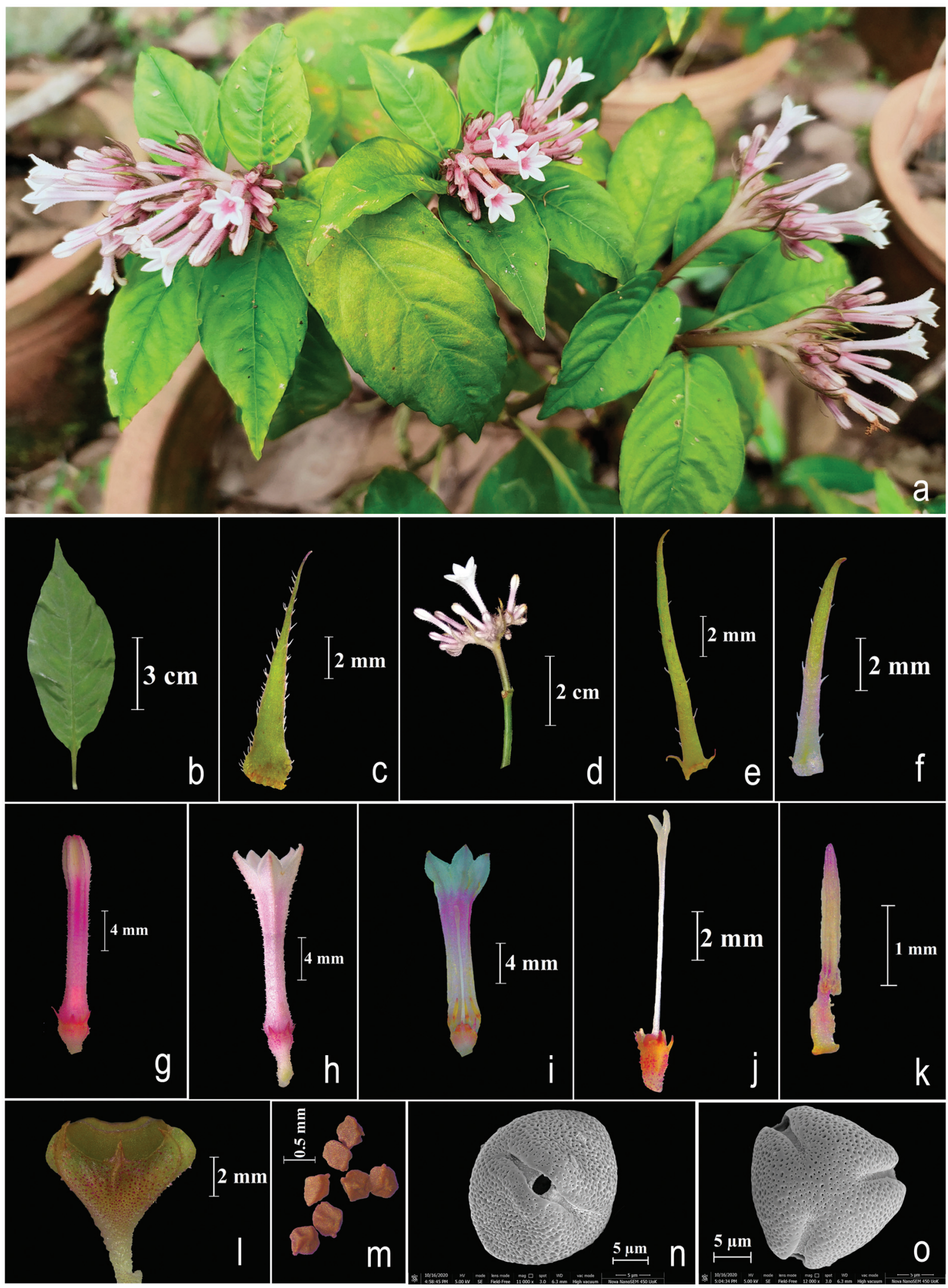

Fig. 1. Ophiorrhiza brunonis var. johnsonii Hook.f.: a. Habit; b. Leaf-adaxial side; c. Stipule; d. Inflorescence; e. Bract; f. Bracteole; g. Flower bud; h. Flower; i. Longitudinal section of a flower; j. Pistil; k. Stamen; I. Fruit; m. Seeds; n. SEM image of pollen, equatorial view; 0. SEM image of pollen, polar view (from Akhilesh S.V. Nair, Gangaprasad A. \& K.B. Rameshkumar 10828; photos by S.V. N. Akhilesh). 


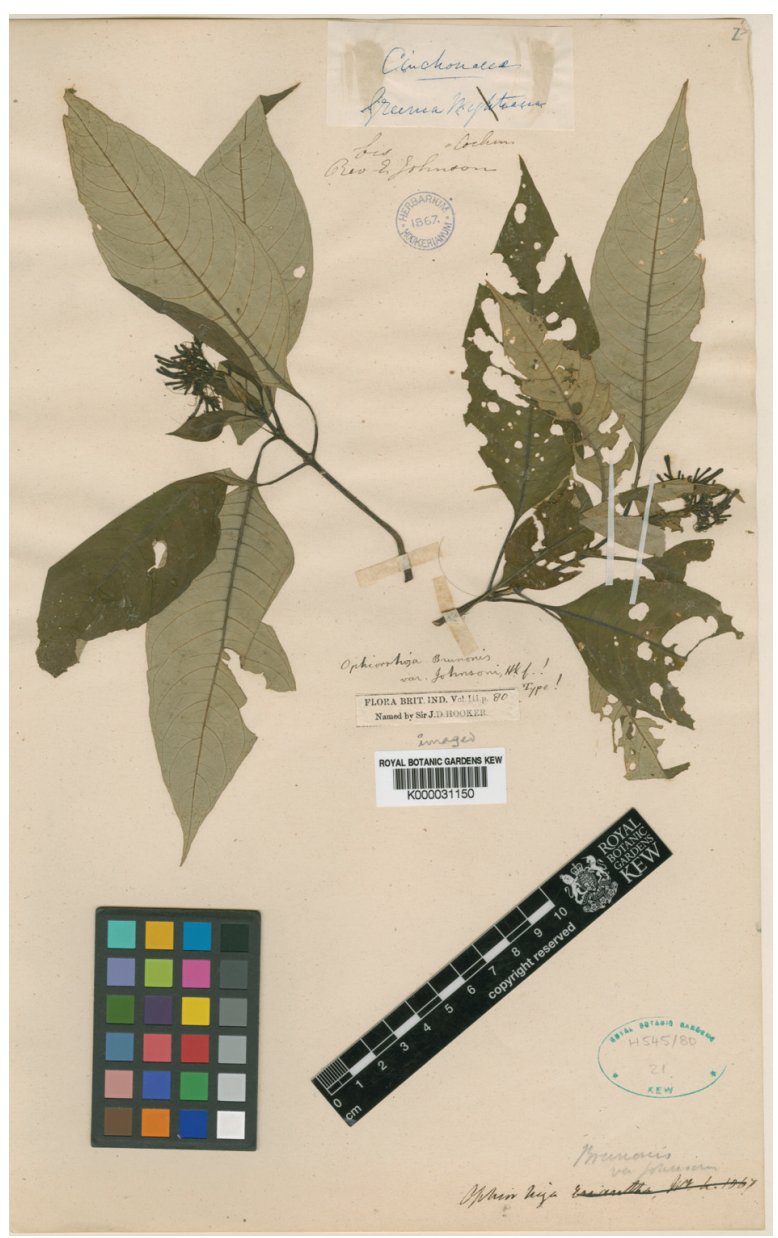

Fig. 2. Lectotype of Ophiorrhiza brunonis var. johnsonii Hook.f. (K000031150). (C) The Board of Trustees for the Royal Botanic Gardens, Kew. Reproduced with permission.

above, puberulous on nerves beneath; lateral nerve pairs 8-12; petioles $1-2 \mathrm{~cm}$ long, puberulous; stipules 7-11.5 mm long, subulate or linearlanceolate, entire, puberulous. Inflorescence terminal, sub-corymbose cymes, $2.5-3 \mathrm{~cm}$ across; peduncles $2-2.5 \mathrm{~cm}$ long, puberulous. Flowers $13-$ $20 \mathrm{~mm}$ long; bracts $10-15 \mathrm{~mm}$ long, linear or filiform, slightly puberulous; bracteoles $8-11 \mathrm{~mm}$ long, linear or filiform, slightly puberulous; pedicels 0.7-1 mm long, slightly puberulous. Hypanthium $1-1.8 \times 1.5-2 \mathrm{~mm}$, obovoid, slightly puberulous. Calyx lobes $0.9-1.6 \times 0.6-0.8 \mathrm{~mm}$, subulate, acute, slightly puberulous. Corolla tube $12-17 \mathrm{~mm}$ long, infundibuliform, narrow, slightly puberulous outside, villous within; lobes 2-2.5 × 0.5-1 mm, ovate-lanceolate, acute. Stamens adnate to the base of corolla, inserted; filaments $0.2-0.7 \mathrm{~mm}$ long, glabrous; anthers $1.8-2.25 \mathrm{~mm}$ long, narrowly oblong with obtuse apex. Ovary $0.75-1 \times 1-1.25$ $\mathrm{mm}$; disc $0.6 \mathrm{~mm}$ high; style $8-11 \mathrm{~mm}$ long, glabrous; stigma 2-lobed, 1.7-2.25 mm long, lobes lanceolate, acute, glabrous. Capsules 3-4 × 5-5.3 $\mathrm{mm}$, crowded, slightly puberulous, bilocular, locules ovate-oblong, tip slightly inclined outwards. Seeds $0.5-0.6 \times 0.4-0.5 \mathrm{~mm}$, irregularly angular, glabrous, brown; testa areolate, areoles alveolate, wall of the areole thin with several tubercles on it and hooded over the areolar space.

Pollen: Pollen grains oblate-spheroidal, angular in polar outline, polar axis $(\mathrm{P}) \times$ equatorial axis $(\mathrm{E})=$ $18-22 \times 21-22.5 \mu \mathrm{m}$, tricolporate; colpi 12-16 $\times$ 2.5-3.5 $\mu \mathrm{m}$, tapering to acute ends; ora circular, 2.5-3.5 $\mu \mathrm{m}$ in diameter; sexine $2.25 \mu \mathrm{m}$, nexine 0.25 $\mu \mathrm{m}$, micro-reticulate; surface lumen diameter 0.1$0.3 \mu \mathrm{m}$.

Flowering \& fruiting: Flowering from March to October and fruiting from August to December.

Habitat: Grows in moist, shady places of rocky slopes at an altitude of 1100-1200 m along with Ophiorrhiza barberi Gamble, O. eriantha Wight, Andrographis producta (C.B.Clarke) Gamble (Acanthaceae), Argostemma courtallense Arn. (Rubiaceae), Sarcandra chloranthoides Gardner (Chloranthaceae).

Distribution: Endemic to southern Western Ghats.

Specimens examined: INDIA, Kerala, Thiruvananthapuram district, Chemunji Hills, N 840'53.7", E 77¹1'16.1", 1100-1200 m, 26.12.2019, Akhilesh S.V. Nair 10828 (KUBH).

Typification: Ophiorrhiza brunonis var. johnsonii was originally described by Hooker (1880) based on the specimens collected by Rev. E. Johnson from Cochin. There are two sheets available at $\mathrm{K}$ and both were used by Hooker for the description. Deb and Mondal (1997) designated Johnson s.n. at K as type and did not specify a single specimen. Thus, the typification by Deb and Mondal (1997) could be considered as a first-step lectotypification. Since the two specimens on the sheet K000031150 (Fig. 2) is 
complete, and agrees well with the details provided in the protologue, it is designated here as the second-step lectotype as per Art. 9.17 of the ICN (Turland et al., 2018) and the other specimen (K000031151 digital image!) consequently as the isolectotype.

Notes: Ophiorrhiza brunonis var. johnsonii can be discriminated from the typical variety O. brunonis var. brunonis by its puberulous stem and stipules, longer corolla tube and style.

\section{Acknowledgments}

The authors are grateful to the Head, Department of Botany, University of Kerala for providing the facilities, and the Council of Scientific and Industrial Research for the financial assistance in the form of Junior Research Fellowship. The authors are thankful to the Kerala Forest Department for the necessary forest permission to collect the specimen from Chemunji Hills.

\section{Literature Cited}

BREMER B. \& T. ERIKSSON 2009. Time tree of Rubiaceae: phylogeny and dating the family, subfamilies, and tribes. International Journal of Plant Sciences 170(6): 766-793. https://doi.org/10.1086/599077
DEB D.B. \& D.C. MONDAL 1997. Taxonomic revision of the genus Ophiorrhiza L. (Rubiaceae) in Indian subcontinent. Bulletin of the Botanical Survey of India 39: $1-148$.

GAMBLE J.S. 1921. Flora of the Presidency of Madras. Adlard \& Co., London.

HAREESH V.S. \& M. SABU 2018. The genus Ophiorrhiza (Rubiaceae) in Andaman and Nicobar Islands, India with a new species. Phytotaxa 383(3): 259-272. https:// doi.org/10.11646/phytotaxa.383.3.3

HOOKER J.D. 1880. The Flora of British India. Volume 3. L. Reeve \& Co. Ltd., London.

NAYAR T.S., BEEGAM A.R. \& M. SIBI 2014. Flowering plants of the Western Ghats, India. Jawaharlal Nehru Tropical Botanic Garden and Research Institute, Thiruvananthapuram.

POWO. 2021. Plants of the World Online. Facilitated by the Royal Botanic Gardens, Kew. Published on the Internet: http://plantsoftheworldonline.org/ (Accessed on 02.12.2021).

TURLAND N.J., WIERSEMA J.H., BARRIE F.R., GREUTER W., HAWKSWORTH D.L., HERENDEEN P.S., KNAPP S., KUSBER W.H., LI D.Z., MARHOLD K., MAY T.W., MCNEILL J., MONRO A.M., PRADO J., PRICE M.J. \& G.F. SMITH (eds.) 2018. International Code of Nomenclature for algae, fungi, and plants (Shenzhen Code) adopted by the Nineteenth International Botanical Congress Shenzhen, China, July 2017. Regnum Vegetabile 159, Volume 38. Koeltz Botanical Books, Glashütten. https://doi.org/ 10.12705/Code. 2018 